NBER WORKING PAPER SERIES

\title{
THE EFFECTS OF AGGREGATE AND GENDER-SPECIFIC LABOR DEMAND SHOCKS ON CHILD HEALTH
}

\author{
Marianne Page \\ Jessamyn Schaller \\ David Simon \\ Working Paper 22394 \\ http://www.nber.org/papers/w22394 \\ NATIONAL BUREAU OF ECONOMIC RESEARCH \\ 1050 Massachusetts Avenue \\ Cambridge, MA 02138 \\ July 2016
}

We thank seminar participants at California State University San Luis Obispo, University of California Riverside, University of Houston, University of Texas-Austin, and Texas A and M University, and conference participants at the American Economic Association Annual Meeting, the Society of Labor Economists Annual Meeting, the International Health Economics Association Annual Meeting, and the American Society of Health Economists Biennial Conference. We are grateful to Jason Lindo and Gary Solon for his helpful comments, and to Gaetano Basso and Esra Kose for their excellent research assistance. This project was supported by funding from National Science Foundation (Grant \#1327768), the University of California Davis Interdisciplinary Frontiers in the Humanities and Arts Grant, and the U.S. Department of Health and Human Services. The views expressed herein are those of the authors and do not necessarily reflect the views of the National Bureau of Economic Research.

NBER working papers are circulated for discussion and comment purposes. They have not been peer-reviewed or been subject to the review by the NBER Board of Directors that accompanies official NBER publications.

(C) 2016 by Marianne Page, Jessamyn Schaller, and David Simon. All rights reserved. Short sections of text, not to exceed two paragraphs, may be quoted without explicit permission provided that full credit, including $\odot$ notice, is given to the source. 
The Effects of Aggregate and Gender-Specific Labor Demand Shocks on Child Health Marianne Page, Jessamyn Schaller, and David Simon

NBER Working Paper No. 22394

July 2016

JEL No. I1,J0,J23

\begin{abstract}
$\underline{\text { ABSTRACT }}$
In this paper, we estimate the relationship between cyclical changes in aggregate labor market opportunities and child health outcomes. In addition to using state unemployment rates to proxy for labor market conditions, as is common in the existing literature, we construct predicted employment growth indices that allow us to separately identify demand-induced changes in labor market opportunities for fathers and mothers. In contrast with prominent studies of adult health, we find no evidence that negative shocks to general economic conditions are associated with improvements in contemporaneous measures of children's health. We do find, however, that focusing on gender-inclusive economic variables obscures the extent to which the labor market affects children. Specifically, we find evidence that improvements in labor market conditions facing women are associated with worse child health, while improvements in men's labor market conditions have smaller positive effects on child health. These patterns, which are consistent with previous findings on the effects of individual parental employment and job displacement, suggest that family income and maternal time use are both important mechanisms mediating the effects of aggregate labor market conditions on child health.
\end{abstract}

Marianne Page

Department of Economics

University of California, Davis

Davis, CA 95616-8578

and NBER

mepage@ucdavis.edu

Jessamyn Schaller

Department of Economics

University of Arizona

McClelland Hall 401PP

Tucson, AZ 85721

and NBER

jschaller@email.arizona.edu
David Simon

University of Connecticut

Department of Economics

365 Fairfield Way, Unit 1063

Storrs, CT, 06269-1063

david.simon@uconn.edu

A online appendix is available at http://www.nber.org/data-appendix/w22394 
In this paper, we investigate the extent to which changes in labor market opportunities affect children's health. An extensive literature documents that negative shocks to labor market demand are, perhaps counter-intuitively, associated with reductions in mortality and improvements in adult health. ${ }^{1}$ We know very little, however, about how children's health responds to changes in labor market conditions. $^{2}$ Understanding this relationship is important, as health in early life is increasingly appreciated as a significant input to human capital development and a determinant of long-term health and socio-economic status (Almond and Currie, 2011). A contemporaneous relationship between labor market opportunities and children's health may have important implications for the wellbeing of the next generation of workers.

Economic theory (e.g. Grossman, 1972) does not provide clear predictions about how changes in aggregate labor market conditions should affect child health. On one hand, the decreases in family income that typically accompany a labor market contraction might lead to reductions in parental investments in children's health. ${ }^{3}$ On the other hand, declining labor market opportunities are associated with reductions in the opportunity cost of parental time, which could lead to improvements in children's health by causing parents to substitute parental care for market-based childcare (reducing their children's exposure to infectious diseases, for example) or through increases in other time-intensive health investments. Meanwhile, both recessions and individual job loss have been linked to declines in adult mental health (e.g. Dooley, Catalano, and Rook, 1988; Fenwick and Tausig, 1994; Bradford and Lastrapes, 2014; Schaller and Stevens, 2015), which may affect children's health either directly or indirectly (Conger and Conger, 2007). When combined with cyclical changes in environmental

\footnotetext{
${ }^{1}$ A non-exhaustive list of studies includes Ruhm (2000, 2003, 2005a, 2005b), Ruhm and Black (2002), Evans and Graham (1988), Gruber and Frakes (2006), Stevens, Miller, Page, and Filipski (2015), Xu (2013). Ruhm (2015) shows that the relationship between recessions and adult mortality has weakened during the Great Recession but remains pro-cyclical, particularly for deaths due to cardiovascular disease and transport accidents.

${ }^{2}$ Two exceptions are Dehejia and Lleras Muney (2004), and Lindo (2015). Both of these studies focus on infant health (mortality and birth weight).

${ }^{3}$ Reductions in employer-sponsored health insurance coverage in an economic downturn may also lead to reductions in children's health. However, Cawley, Moriya, and Simon (2015) document that children's overall health insurance coverage is not significantly correlated with the state unemployment rate, suggesting that increases in public health insurance coverage may counteract reductions in employer-sponsored coverage.
} 
contributors to children's health such as pollution, the multitude of potentially changing within-family inputs leaves the overall relationship as an empirical question.

Moreover, there is reason to believe that the estimated effect of an aggregate economic downturn on children's outcomes might mask contradictory effects of changes in labor market outcomes (employment, hours, and wages) for mothers versus fathers. For example, as fathers are often primary earners, average income effects from changes in fathers' labor market opportunities may be larger. Research in psychology and sociology has suggested that fathers may also experience greater increases in stress than mothers following job displacement (Kalil and Ziol-Guest, 2008). Meanwhile, women are more likely than men to substitute time in the labor market directly for time spent with children, which suggests that changes in mothers' labor market opportunities may have larger effects on the source and quality of child care (see, e.g., Aguiar, Hurst, and Karabarbounis, 2013; Lindo, Schaller, and Hansen, 2013; Pailhé and Solaz, 2012). Perhaps not surprisingly, recent empirical studies exploiting plausibly exogenous changes in individual employment status do find differing effects of fathers' and mothers' employment on child health, typically finding that mothers' employment is associated with worse health for children, while fathers' employment has the opposite effect. ${ }^{4}$

A key challenge in estimating the effects of shocks to parental labor market outcomes on child health is endogeneity. In particular, family income and labor supply decisions are likely to be correlated with unobservable preferences and attributes of children and families that are related to child health. It is also likely that child health directly affects parental labor supply. These concerns are particularly salient when considering maternal employment outcomes, making it difficult to compare the effects of labor market shocks facing fathers and mothers using standard (individual or aggregate) employment variables.

This paper makes three contributions. First, we are among the first to provide estimates of the relationship between cyclical changes in aggregate labor market opportunities and children's health in the United States, and (to our knowledge) the first to consider cyclical variation in child health outcomes

\footnotetext{
${ }^{4}$ See, e.g. Anderson, Butcher, and Levine, 2003; Gennetian et al., 2010; Morrill, 2011; Lindo, 2011; Liu and Zhao, 2011; and Schaller and Zerpa, 2015.
} 
other than infant health or mortality. Combining restricted data from the National Health Interview Survey with state monthly unemployment rates, we examine the effect of contemporaneous aggregate employment opportunities on a variety of outcomes for children, including general ratings of health, the incidence of specific health conditions, and a standardized index summarizing a set of costly health conditions. This analysis complements existing work that uses a similar empirical approach to explore changes in adult health outcomes over the business cycle.

Second, in order to address the potential endogeneity of aggregate unemployment rates, we generate predicted employment growth rates that exploit variation in base-period industry employment shares across states, together with national rates of industry employment growth. These "shift-share" indices, which are similar to those used by Bartik (1991), Katz and Murphy (1992), and Blanchard and Katz (1992), allow us to isolate variation in child health due to demand-induced changes in aggregate labor market opportunities.

Finally, in a variation on the shift-share strategy, we create separate predicted employment growth rates that capture plausibly exogenous changes in labor demand facing men and women. This approach, which is in the spirit of the work of Schaller (2016) and of Aizer (2010) and Bertrand, Kamenica, and Pan (2015) (who use a similar strategy to develop indices of male-female relative earnings), allows us to separately estimate the effects of shocks to aggregate labor market opportunities facing fathers and mothers on child health, bringing broader perspective to a literature that has thus far focused exclusively on individual employment shocks.

Our findings are summarized as follows. In contrast with recent studies that focus on adult health, we find little evidence that general labor demand conditions are associated with improvements in contemporaneous measures of children's health. A limited number of health outcomes appear to vary with the unemployment rate, but the magnitudes of these estimated effects are small and the associations become weaker when we use predicted employment growth as our measure of economic conditions.

Turning to the effects of gender-specific labor market conditions, we find that focusing on broad measures of employment opportunities obscures the true extent to which the labor market affects children. 
Specifically, the pattern of estimates strongly indicates that improvements in labor market conditions facing women are associated with worse child health while improvements in men's labor market conditions are associated with better child health. These patterns are consistent across all outcomes, and many of the estimates are non-negligible in magnitude and statistically different from zero. Thus, it appears that the correlation between children's health and a gender-inclusive measure of employment opportunities averages together positive associations between male labor market opportunities and child health and negative associations between female labor market opportunities and child health, masking important underlying patterns.

One possible interpretation of these patterns is that mothers and fathers may provide different inputs into the production of children's health, with mothers making relatively larger time investments, on average, and fathers providing higher levels of monetary support. While income losses that are associated with negative employment shocks are accompanied by increases in the amount of time that parents have available to invest in child-care-related activities, the balance between these two effects is likely to be different for mothers and fathers. Our findings underscore the importance of both monetary and time inputs in the production of children's health.

The remainder of our paper is organized as follows. In Section II we provide a review of the related literature, showing that there are reasons to expect that labor market opportunities might affect children's health, and that the impact of male and female employment conditions might be expected to differ. In Section III we describe our data. We then explain our empirical framework in Section IV, where we also describe the construction of the predicted employment growth rates that we use to address potential endogeneity. Our results are presented in Section V, followed by a discussion of potential confounding factors and possible mechanisms in Section VI. Section VII concludes.

\section{Literature and Theoretical Framework}

Many studies have documented that higher unemployment rates are associated with reductions in overall mortality (Ruhm, 2000; 2003; 2005a; 2005b), reductions in mortality due to cardiovascular 
disease and transportation accidents (Ruhm, 2015), and improvements in other measures of health (Ruhm, 2003; 2005b). These relationships are often thought to result from improvements in health-related behaviors that occur as a result of changes in the opportunity cost of time that accompany declining labor market opportunities (Evans and Graham, 1988; Ruhm and Black, 2002; Ruhm, 2005b; Gruber and Frakes, 2006; Freeman, 1999; Xu, 2013). ${ }^{5}$ Nearly all of these studies focus on adult health, but mortality is known to vary cyclically across all age groups. Stevens et al. (2015), for example, find that a one percentage point increase in the unemployment rate is associated with a $0.3 \%$ reduction in mortality overall, but a $1.4 \%$ reduction in mortality among children between the ages of 0 and 4 , and a statistically insignificant reduction of $0.04 \%$ among adults between the ages of 45 and 61 . This suggests that, relative to adults, children's health may be particularly sensitive to cyclical variation in labor market conditions.

To our knowledge, the only studies to date that have focused on the impact of aggregate economic conditions on children's health have focused on infant health. Using U.S. vital statistics data, Dehejia and Lleras-Muney (2004) document that higher unemployment rates are associated with reductions in infant mortality, and Dehejia and Lleras-Muney (2004) and Lindo (2015) find that higher unemployment rates are associated with reductions in the incidence of low birthweight. Dehejia and Lleras-Muney attribute these effects to both positive selection and changes in maternal health behaviors, such as smoking and drinking. They conclude that changes in the opportunity cost of women's time may be an important determinant of cyclical changes in health during pregnancy, and more generally suggest that reducing the opportunity cost of maternal time inputs may be a possible mechanism for improving children's health outcomes.

Dehejia and Lleras-Muney's conclusion is echoed in a larger literature that focuses on identifying the effect of maternal employment on children's health outcomes. That literature, largely framed in the context of understanding the implications of long-term trends in women's labor force participation, generally finds that mothers' employment negatively affects children's health. An empirical challenge

\footnotetext{
${ }^{5}$ An exception is Stevens et al. (2015), who note that most of the cyclically induced deaths are among older individuals, for whom the opportunity cost of time is not likely to be strongly affected by changes in labor demand.
} 
faced by all of these studies, however, is that mothers' labor supply decisions may be partly determined by unobserved factors that also affect their children's outcomes. While two recent studies make some headway on this endogeneity problem - Gennetian, Hill, London, and Lopoo (2010) use experimental variation in maternal work incentives that was generated by the 1990 s welfare-to-work experiments, and Morrill (2011) uses variation in maternal employment induced by the youngest child's eligibility for kindergarten - there is a dearth of causal evidence on the effect of maternal employment on children's health.

Fewer studies directly investigate the impact of father's employment, but among those that do, there is no evidence that paternal employment has negative effects on children's health, and there is some suggestive evidence that it has positive causal effects (Anderson, Butcher, and Levine, 2003; Phipps, Lethbridge, and Burton, 2006; Morrissey, Dunifon, and Kalil, 2011). Lindo (2011), for example, compares the birth weight of infants born before and after a paternal job displacement, and finds that father's job loss reduces birthweight by over four percent. When considered together with the literature on maternal employment, this finding suggests that mothers and fathers may influence the production of children's health very differently. Recent studies that consider the impacts of both mothers' and fathers' job losses or unemployment provide further evidence in this regard: Schaller and Zerpa (2015) find that maternal job loss is associated with reductions in the incidence of acute infectious conditions, while paternal job loss is associated with worse mental health among children. Liu and Zhao (2011) examine the impacts of job displacement in China and find that while mother's job loss has no effect on children's height and weight, father's job loss has a negative impact. By contrast, using Swedish data and focusing on the effects of having a parent who is currently unemployed and searching for work, Mork, Sjogren, and Svaleryd (2014) find that maternal (active) unemployment spells lead to a greater increase in hospitalizations among children than paternal unemployment spells.

There are a number of reasons that mothers' and fathers' job losses may have different effects on the production of child health. Even conditional on work status, mothers spend approximately twice as much time engaged in child-care-related activities as do fathers (Guryan, Hurst and Kearney, 2008; Kalil and 
Ziol-Guest, 2013), and more of that time is devoted to routine care (Bryant and Zick, 1993; Pleck, 1997). Changes in mothers' employment status may, therefore, have larger impacts on time inputs into children's health. Recent research suggests that, indeed, recession-induced declines in work generate relatively larger increases in the amount of time mothers spend with their children (Aguiar et al., 2013; Lindo et al., 2013). These findings suggest that if parental time inputs are important to the production of children's health then a mother's job loss may have a more positive effect than a father's job loss.

Furthermore, in the majority of American families, husbands' earnings contribute more to household income than wives' earnings (Bertrand et al., 2015). For most families, therefore, a father's job displacement will generate a larger shock to family income. Given the well-documented positive correlation between income and child health (Case, Lubotsky, and Paxson, 2002), the income losses associated with a paternal job loss might have a negative impact on child health that exceeds that of a maternal displacement. Paternal job loss might also have a larger effect on the level of stress that a family experiences. Existing studies have shown that negative employment shocks are associated with reductions in adult mental health (Brand, Levy, and Gallo, 2008; Browning and Heinesen, 2012; Schaller and Stevens, 2015) and impaired family functioning (Conger et al., 1994). The Family Stress Model (Conger et al., 1994) predicts that this will have a direct, negative, effect on children's outcomes.

By suggesting that male and female employment opportunities may have different effects on children's health, the opposing mechanisms outlined above make it difficult to predict the sign of the relationship between overall labor market opportunities and children's health. It is also important to keep in mind that parental job loss is only one route by which labor market conditions might affect children's health. Recessions lead to changes in time use, reduced earnings and wealth, and higher stress levels even among parents who hold onto their jobs (Dooley et al., 1988; Fenwick and Tausig, 1994; Kalil and ZiolGuest, 2013; Morrill and Pabilonia, 2015). If such channels are important to children's health outcomes, then studies that focus on the impacts of individual employment shocks such as parental job displacement will understate the overall effects that result from labor market contractions. Labor market contractions may also affect children's health through environmental, rather than family level changes. For example, a 
growing body of research documents that pollution from manufacturing activity and traffic congestion affects children's health. ${ }^{6}$

\section{Data}

Our analyses are based on data from the 1997-2012 National Health Interview Survey (NHIS), which is one of the primary surveys used to monitor health trends in the United States population. The NHIS is a repeated cross-sectional survey that collects health information on $34,000-40,000$ families each year. We use the restricted-use version of the NHIS because the public-use version does not include state identifiers, which are necessary to our identification strategy: a child's state of residence is required to assign the relevant state/year labor market variables. We include in our main sample all children between the ages of 0 to 17 (or 5 to 17 for school-related outcomes). ${ }^{7}$

The NHIS has two components that we use in our analyses. The Person-Core questionnaire includes demographic and health data for each member in each surveyed household. The Sample Child questionnaire includes detailed questions about health and well-being for one randomly sampled child from each household. The answers to the questions in the Sample Child survey are provided by a knowledgeable adult, who is the child's parent more than 90 percent of the time. Because we use data from these two separate NHIS files, the number of observations in our sample varies across outcome variables. In particular, the estimates for outcomes from the Sample Child file are based on samples that are smaller than those for outcomes from the Person-Core file. ${ }^{8}$

We focus on a set of health outcomes that are relatively common among children and have a reasonable likelihood of exhibiting transitory fluctuations over time. Our outcome variables include three

\footnotetext{
${ }^{6}$ For example, Chay and Greenstone, 2003; Currie and Neidell, 2005; Currie, Neidell and Schmieder, 2009; Currie and Walker, 2011; Currie and Schmieder, 2009; Knittel, Miller and Sanders, 2011; and Sanders, 2012.

${ }^{7}$ The NHIS changed substantially in 1996, making it difficult to include earlier years of the survey due to the survey structure (and many of the outcome variables) not being comparable.

${ }^{8}$ Since children are randomly selected within households for the Sample Child file, we do not expect that treatment effects should be heterogeneous across the different samples. However, we have confirmed that results for variables in the Person-Core file are similar when estimated on the sample of children included in the Sample Child file.
} 
measures of overall health: ${ }^{9}$ 1) whether the parent reports that the child is in fair or poor health, 2) whether the parent reports that the child is in excellent health, and 3) the number of days in the last year that a child over the age of 5 has missed school due to illness. ${ }^{10}$ The indicators for fair/poor and excellent health status comes from a survey question where parents are asked to rank the health of their children on a scale of one to five with one being excellent and five being poor. Roughly $2 \%$ of parents report that their child is in fair or poor health, while $55 \%$ of the sample reports that their children are in excellent health.

We also examine the effect of labor demand conditions on a set of more narrowly defined health outcomes that are plausibly linked to economic conditions in the short run and unlikely to be subjective or to remain undiagnosed (and thus will not be highly sensitive to changes in respondent mood and/or medical care utilization). Our choice of specific health conditions is further motivated by the Agency of Health Care Research and Quality's (AHRQ) ranking of childhood health conditions by total expenditures (Soni, 2014). According to this publication, the five most costly childhood health conditions are: mental disorders, asthma, trauma-related disorders, respiratory infections, and ear infections. As a large share of costs related to these health outcomes is born outside of the household (for example, according to Soni, 2014, over half of total expenditures on asthma and mental health were paid for by Medicaid in 2011), changes in the incidence of these conditions may have important policy implications. In our data, we identify (1) whether a child has had an asthma attack in the last year, (2) whether the child has experienced three or more ear infections in the last year, (3) whether a child has experienced severe emotional difficulties in the last six months, and (4) whether the child has experienced an injury in the past three months. ${ }^{11}$

\footnotetext{
${ }^{9}$ Parent-reported health (1-5 scale), activity limitations, and injuries are part of the Person-Core questionnaire and are available for every child in the NHIS sample. All other health outcomes that we consider are from the Sample Child questionnaire, and are reported for one randomly selected child per household.

${ }^{10} \mathrm{We}$ acknowledge that the number of sick days could be affected by parental employment status, independent of a child's underlying health, and interpret our results accordingly.

${ }^{11}$ Unfortunately, we are unable to investigate childhood obesity as an outcome. The NHIS stated in 2008 that they had substantial concerns with how they had been recording the data on child height and weight. In particular, they had not been conducting internal consistency checks for extreme values. In 2008, they improved their survey
} 
Each of the specific health outcomes that we consider is plausibly linked to labor market conditions through changes in family income, parental time use, and family stress. For example, changes in child mental health are most likely to be directly related to their parents' mental health, ${ }^{12}$ while changes in the incidence of ear infections are more likely to be a result from changes in children's time use. The incidence of injuries may be associated either with changes in time use such as changes in daycare attendance or sports participation, or with changes in parental mental health, if injuries reflect child maltreatment. ${ }^{13}$

For asthma in particular, there are a multitude of potential mechanisms linking economic conditions to the incidence of asthma among children. For example, childhood asthma attacks are known to be triggered by air pollutants, the level of which varies with aggregate economic activity, and parental stress has been found to enhance the effect of environmental pollution on childhood asthma incidence (Shankardass et al., 2009). Furthermore, exposure to dust, animal hair, cockroaches, and molds is associated with asthma attacks (Institute of Medicine, 2000), and such factors are linked to the cleanliness of a home, possibly becoming more prevalent when parents spend less time at home. Childhood asthma attacks have also been linked with exposure to second-hand smoke (Sabia, 2008), and there is evidence that adult smoking also fluctuates with the business cycle (Ruhm, 2005b). Finally, the incidence of asthma symptoms may depend on children's level of physical activity, the availability of asthma medication, and whether children and their parents have had counseling on handling medication regimes and dealing with oncoming attacks.

Throughout our analysis we acknowledge that the relative importance of different mechanisms is likely to vary with the condition considered, and interpret our findings accordingly. However, because there are many outcome variables, we also create a standardized index of "costly conditions" in the spirit

methodology . However, at that time, they also stopped collecting data on height and weight for children younger than 12 (National Center for Health Statistics, 2009).

${ }^{12}$ Several existing studies have linked adult mental health to aggregate economic conditions, including Blanchflower and Oswald, 2004; Dooley and Catalano, 1984; Dooley et al., 1988; Fenwick and Tausig, 1994. ${ }^{13}$ Lindo et al. (2013) find that overall economic conditions are not strongly related to rates of substantiated child abuse, but they find that increases in male layoffs per capita are associated with increases in abuse rates, while increases in female layoffs per capita are associated with reductions in abuse rates. 
of similar indices put forth by Kling, Liebman, and Katz (2007) and Anderson (2008). The components of the index include: whether the child has experienced severe emotional difficulties, whether the child has had an asthma attack, whether the child has experienced an injury and whether the child has experienced three or more ear infections. We create a standardized z-score for each variable by subtracting the mean and dividing by the standard deviation. ${ }^{14}$ We then create the index by averaging across the standardized z-score versions of each of the individual measures. Using this index as an additional dependent variable improves statistical power (Kling et al., 2007). Regressing our labor market indicators on this index also serves as a unified hypothesis test for statistical significance across the included outcomes, helping us guard against type-one error due to multiple hypothesis testing (Anderson, 2008).

We merge the NHIS data with state- and time-varying economic and demographic data obtained from other sources. State monthly unemployment rates are from the Bureau of Labor Statistics. We use the average unemployment rate in the 12 months preceding the NHIS interview. ${ }^{15}$ Predicted employment growth rates, described in detail below, are created using data from the decennial Census and Current Population Surveys. State population shares by race/ethnicity and educational attainment are from the Current Population Survey (through 1999) and the American Community Survey (after 1999). Data on housing prices at the state level are from the Federal Housing Finance Agency House Price Index. Data on the number of births in each state-year are obtained from U.S. vital statistics. Table 1 shows summary statistics for our key health outcomes, labor market indicators, and demographic controls. ${ }^{16}$

\footnotetext{
${ }^{14}$ To calculate the means, we first restrict the sample to individuals in the relevant cohorts for whom there is information on all variables that are included in the Z-score, and we then calculate each variable's mean value based on that sample.

${ }^{15}$ The pattern and magnitude of the estimates are robust to alternative specifications in which we replace the twelvemonth average of the unemployment rate with either the six-month average or the unemployment rate in the month of the interview. We also find similar patterns when using the employment to population ratio instead of the unemployment rate.

${ }^{16}$ In Table 1, and all future tables, the means and coefficient estimates have been multiplied by 100 , with two exceptions: the "Costly Conditions" index results are presented as the fraction of a standard deviation, and the "Sick Days" results are presented as number of days.
} 


\section{Empirical Framework}

\section{A. Sample Estimating Equation}

We use micro-level data to estimate a model that leverages variation across US states in the timing and severity of labor market shocks. We estimate a variant of a difference-in-differences model that allows us to compare health outcomes among children living in a state that is experiencing a labor market contraction to those living in the same state when employment opportunities are better, while controlling for nationwide shocks. Specifically, we estimate equations like:

$$
Y_{i a s t}=\psi_{s}+\phi_{a t}+\beta U_{s t}+\pi X_{i s t}+\varepsilon_{i a s t}
$$

where $Y_{\text {iast }}$ represents a health outcome for child i, currently age $a$, living in state $s$, observed in year $t$. $\psi_{s}$ is a vector of state fixed-effects, allowing us to control for unobserved differences across states, and $\varphi_{a t}$ is a vector of age-year fixed effects, allowing us to control for changes over time in age-specific child health outcomes. $U_{s t}$ is the unemployment rate in state $\mathrm{s}$ in year $\mathrm{t}$, and $X_{i s t}$ is a vector of individual controls including parents' marital status, child race, child gender, mother's education, and month of interview. In some specifications we add controls for state-level factors that may be correlated with both labor market conditions and children's health, including average home prices, the number of births, the fraction of the population in each of four education groups (high school dropout, high school, some college, and college educated), and the fraction of the population in each of three race categories (white, black, other). We also test the robustness of our results to the inclusion of state-specific linear trends to control for unobserved variables correlated with health that change linearly over time within states. Our standard error estimates are clustered at the state level, to account for the fact that the error term may be correlated across time periods within each state.

\section{B. Predicted Employment Growth Rates}

Though unemployment rates are commonly used as an indicator of local economic conditions in studies of the effects of business cycles on individual and family outcomes, their use is potentially problematic in this setting. In particular, because the denominator of the unemployment rate measures 
active labor force participation, unemployment rates are likely to capture changes in labor supply as well as changes in labor demand. This increases the likelihood that changes in unemployment will be correlated with changes in other unobserved variables that may also be related to child outcomes. There also may be a direct reverse-causality bias. If exogenous declines in children's health cause a decline in parents' labor force attachment, the denominator of the unemployment rate will decline and, if total employment remains fixed, the measured unemployment rate will increase. As a result, OLS coefficients may be biased downward. Another potential source of bias is measurement error: unemployment rates are a noisy measure of actual labor market opportunities. This is especially true in an economic downturn: because "discouraged workers" (workers who want to be employed but are no longer actively searching for a job) are not counted in measured unemployment rates, the unemployment rate may not be capturing the full extent of the contraction.

As an alternative to unemployment rates, we capture shocks to labor demand by creating an index of predicted employment growth that we use to replace $U_{s t}$ in Equation (1). The approach is based on that of Bartik (1991), Katz and Murphy (1992), and Blanchard and Katz (1992). We create a predicted employment growth rate by weighting the national industry-specific employment growth rates by industry shares in each state in a base period and then summing over industries within each state-year as follows:

$$
D_{s t}=\sum_{i} G_{i t} * \frac{E_{i s 0}}{E_{s 0}}
$$

where $G_{i t}$ is the growth rate of industry $i$ in year $t$ from the March CPS and $\frac{E_{i s 0}}{E_{s 0}}$ is the ratio of industry $i$ employment in state $s$ to total employment in state $s$ from the 1990 Census. ${ }^{17}$ An average of the predicted employment growth rates (across states) is shown in Appendix Figure A1, along with an average of state unemployment rates.

\footnotetext{
${ }^{17}$ The labor demand indices in this paper are identical to those used by Schaller (2016) to estimate the effects of gender-specific labor demand on fertility, except for the choice of base-period.
} 
Because variation over time in this index is driven by national employment growth rates, it will be uncorrelated with state-level supply shocks, as long as there is no industry for which employment is concentrated in a single state (Blanchard and Katz, 1992). In order to ensure that this is true, while maintaining sufficient cross-sectional variation in the base-period industry composition, we use data from 17 industry categories. ${ }^{18}$ Cross-sectional variation in state employment shares also helps identify the effect of demand shocks, since aggregate demand shocks in a particular industry will have larger employment effects in states where the affected industry makes up a relatively greater share of total employment.

Because the time variation in this predicted employment growth measure is driven by national industry employment growth from March of the previous year to March of the current year (as it is based on March CPS employment estimates), the annual measure will be less accurate the further from March the interview month is. To correct for this, we adjust the timing of the index by weighting the predicted employment growth rates differently depending on the month of interview. For March, we use the current-year index, as it represents predicted employment growth from last March to this March. For February, we put $11 / 12$ weight on this year's index and 1/12 weight on last year's index, since the first month of the reference period would have fallen prior to the previous March CPS. For April, we put 11/12 weight on this year's index and 1/12 weight on next year's index, and so on.

In order to separately estimate the effects of shocks to labor demand facing fathers and mothers, we create analogous predicted employment growth rates that reflect gender-specific labor demand conditions. Specifically, rather than weighting national industry employment growth rates by the base-period share of total state employment in each industry, we weight by the base period share of males or females

\footnotetext{
${ }^{18}$ The 17 industry categories are: (1) agriculture, forestry and fishing (2) mining (3) construction (4) low tech manufacturing (lumber, furniture, stone, clay, glass, food, textiles, apparel and leather (5) basic manufacturing (primary metals, fabricated metals, machinery, electrical equipment, automobile, other transport equipment (excluding aircraft), tobacco, paper, printing, rubber, and miscellaneous manufacturing) (6) high tech manufacturing (aircraft, instruments, chemicals, petroleum) (7) transportation (8) telecommunications (9) utilities (10) wholesale trade (11) retail trade (12) finance, insurance, and real estate (13) business and repair services (14) personal services (15) entertainment and recreation services (16) professional and related services (17) public administration. The division of manufacturing into low-tech and high-tech categories follows Katz and Murphy (1992).
} 
employed in a given state in each industry, summing across industries, by gender, within the state as follows:

$$
D_{s t g}=\sum_{i} G_{i t} * \frac{E_{i s g 0}}{E_{s g 0}}
$$

where $g$ indexes the group (male, female). ${ }^{19}$ These indices, which are similar to those used by Schaller (2016) and to the predicted earnings indices used by Aizer (2010) and Bertrand et al. (2016) to construct male-female earning ratios, can be interpreted as gender-specific predicted employment growth rates. As with the overall labor demand index, adjacent March-March employment growth rates are weighted depending on the month of interview. We include the male and the female indices in the same regression, so the coefficient on the male index represents the effect of a one percentage-point increase in the predicted employment growth rate for males, holding predicted female employment growth constant, and vice versa.

As shown in Appendix Table A1, our male and female shift share indices are correlated in predictable ways with more common, but less exogenous, gender-specific measures of labor market conditions from the Current Population Survey's Merged Outgoing Rotation Groups. For example, the within-gender correlation between predicted employment growth and actual employment growth is 0.67 for women and 0.54 for men, while the cross-gender correlations are not statistically significant. As would be expected, less striking but similar correlations exist between gender-specific measures of predicted employment growth and gender-specific measures of the employment rate. Also of interest is the relationship between our gender-specific indices and gender-specific measures of the unemployment rate. Relative to the female index, the male index is a much stronger predictor of both male and female unemployment rates. This is not surprising as, relative to male unemployment, variation in the female unemployment rate is

\footnotetext{
${ }^{19}$ It would theoretically be possible to construct these indices based on base-period industry employment shares for the subgroup of men and women who are, in fact, fathers and mothers. However, we are concerned about power in the already-small state CPS samples. There are also potential selection issues. In particular, the distribution of employment across industries among all employed women will arguably generate a better proxy for potential labor market opportunities than the employment distribution among the (selected) sample of working mothers.
} 
more likely to reflect variation in labor force participation, which increases among women when there is a decline in male labor market opportunities. ${ }^{20}$

\section{Results}

\section{A. Effects of General Labor Market Conditions on Children's Health}

We begin by estimating the relationship between aggregate employment conditions and children's health outcomes. Table 2 follows the adult health literature and focuses on the unemployment rate as the regressor of interest. We see that although many of the point estimates suggest that labor market contractions are negatively associated with children's health outcomes, most of the results are statistically insignificant. In particular, unemployment rates do not appear to be correlated with parent-reported general health, asthma attacks, ear infections, or the number of sick days a child takes from school. There are, however, two specific health measures for which the association with unemployment rates is positive and statistically significant: injuries and severe emotional difficulties. Not surprisingly, since these two outcomes are components of the costly conditions index, we also see a positive association between the unemployment rate and this summary index.

The coefficients indicate that a one percentage point increase in the state unemployment rate is associated with a five to six percent increase in the number of injuries (depending on the specification), a 10-11 percent increase in the likelihood that a child experienced severe emotional difficulties and a 0.005 0.006 standard deviation increase in costly conditions. These estimated effects, which are robust to the inclusion of both state-level control variables and state-specific linear time trends, imply that an increase in the unemployment rate from 5 percent to 10 percent (the size of the increase in the US unemployment

\footnotetext{
${ }^{20}$ While the employment results in Table A1 reassure us that our male and female predicted employment growth indices are indeed associated with measurable changes in labor market opportunities for men and women, the results for the unemployment rate raise the possibility that the two indices may be capturing different marginal changes in employment, hours, and earnings among their respective populations. We interpret our results with this limitation in mind. We additionally test, in Section VI A, whether the results are robust to the inclusion of a control for the overall state unemployment rate, and find that they are.
} 
rate during the Great Recession) is predicted to increase the incidence of injuries and the incidence of emotional difficulties among children each by approximately 7 per 1000 children.

Notably, these findings contrast both with the literature on changes in adult health over the business cycle, which has generally shown that increased unemployment rates are associated with improvements in adult health, and with the literature on the relationship between unemployment rates and infant health, which has found that economic downturns are associated with reductions in infant mortality and the incidence of low birthweight. On the other hand, they are consistent with recent work looking at the direct effects of parental job displacement on child health: Schaller and Zerpa (2015) find that paternal job loss is associated with worse mental health among children and leads to increases in injuries among children in low-socioeconomic status families.

Because it is not obvious whether the impacts of labor market conditions on child health should be seen immediately or whether it takes time before they are observed, we have also estimated regressions that include both the unemployment rate averaged over the preceding twelve months, and the average unemployment rate 12-24 months prior to the interview month (i.e. the one year lag of the unemployment rate). The results of these analyses are shown in Appendix Table A2, and are largely consistent with those in Table 2. For most outcomes, inclusion of the lagged unemployment rate has a negligible effect on the coefficient estimates, but slightly increases the estimated standard errors. Most of the coefficient estimates on the lagged unemployment rate are also not statistically distinguishable from zero. ${ }^{21}$

Table 3 shows results from regressions in which we replace the unemployment rate with an exogenous index of predicted employment growth (as a reminder, an increase in the right hand side variable now represents a positive shock to economic conditions rather than a negative one). We use this alternate measure of overall economic conditions for two reasons. First, as discussed in the previous section, to the extent that movements in the unemployment rate represent changes in labor supply as well

\footnotetext{
${ }^{21}$ The exception is that an increase in the lagged unemployment rate is associated with a small but significant reduction in the probability that a child is reported to be in excellent health. Inclusion of the lagged unemployment rate also causes the estimated coefficient on the contemporaneous unemployment rate to be noticeably smaller in this regression.
} 
as labor demand, the estimates in Table 2 will be biased if changes in labor supply are related to changes in child health. Second, we estimate the effects of aggregate predicted employment growth rates in order to generate estimates that are more easily compared to the corresponding estimates using gender-specific labor demand indices that are presented in the next section. When we replace unemployment rates with predicted employment growth rates, the statistically significant relationships between labor market conditions and injuries and emotional difficulties disappear. In other words, we find that the state-level aggregate predicted employment growth rate is not significantly associated with any of our child health outcomes.

\section{B. Effects of Gender-Specific Labor Market Conditions on Children's Health}

The estimated overall effects shown in Tables 2 and 3 may mask very different relationships between children's health and contemporaneous male and female labor market opportunities. Aggregate measures of labor market conditions capture changes in labor market opportunities for both men and women, and as discussed in Section II, there are many reasons to believe that male and female labor market conditions potentially have different influences on child health.

We examine this possibility in Table 4, which shows the estimated coefficients on our gender-specific predicted employment growth rates. The pattern of the estimates is striking: across all outcomes, positive labor demand shocks for females are associated with decreases in child health, while positive labor demand shocks for males are associated with improvements in child health. Many of the estimates are substantial and statistically different from zero, and the magnitudes of the coefficients are similar across all three regression specifications. In general, the estimates on the female index are larger in absolute magnitude than the estimates on the male index.

We first focus on the summary index of costly conditions. Here, the estimated coefficients on male employment growth are between -0.008 and -0.009 , while the estimated coefficients on female employment growth are between 0.012 and 0.015 . Both estimates are statistically significant at the five percent level. The magnitude of the coefficient estimates implies that an increase in female predicted 
employment growth of one percentage point increases costly conditions by approximately 0.015 standard deviations, while the same increase in male predicted employment growth reduces costly conditions by approximately 0.009 standard deviations. Moving on to the other general measures of child health, we see the same patterns. In particular, we see that increases in female labor demand result in reductions in the likelihood that a child is reported to be in excellent health and increases in the number of sick days, while the coefficients on male labor demand in the same regressions are statistically insignificant and opposite-signed. ${ }^{22}$

The right-hand side of Table 4 shows the results from regressions using the specific health outcomes that make up the costly conditions index. Again, the contrast between the point estimates for the male and female indices, which is apparent across all specifications and health outcomes, suggests that improvements in labor market opportunities for fathers are associated with improvements in child health while improvements in labor market opportunities for mothers are associated with worse child health. The estimates for two specific health measures particularly stand out: a one percentage point increase in male predicted employment growth is associated with a statistically significant $0.2-0.3$ percentage point decline in the probability that a child has an asthma attack, whereas a one percentage point increase in female predicted employment growth is associated with a comparable (but statistically insignificant) increase. The magnitude of these estimates represents a five percent change in a child's probability of having an asthma attack. Turning to the estimated effects on emotional difficulties, the point estimates on the female index are also large and statistically significant, suggesting that a one percentage point increase in female employment growth leads to an increase in the probability that a child is reported to have severe emotional difficulties of over ten percent.

\section{Discussion}

\section{A. Potential Confounding Factors}

\footnotetext{
${ }^{22}$ Note that the potential bias resulting from an independent effect of maternal employment on sick days, holding health constant, should work in the opposite direction from the estimated effect of female labor demand conditions.
} 
Before proceeding, it is important to discuss and rule out a number of potential confounding factors that might cause us to observe differing effects of male and female labor demand indices on children's health outcomes. In particular, we might be concerned that the male and female labor demand indices are differentially associated with 1) the gender of the reporting parent in the NHIS survey, 2) the mental state of the reporting parent at the time of the interview, 3) the composition of the NHIS sample (due to migration or nonresponse), or 4) unobservable economic factors.

First, if either the gender or the mental state of the reporting parent is associated with the male or female labor demand index, we might be concerned about differential reporting bias. In other words, it may be that reported child health responds differently to the two indices, when true underlying health does not. We examine this possibility, in Appendix Table A3, first by putting the gender of the reporting parent on the left-hand side of our main regression specification and then by putting parents' mental health on the left-hand side. Neither shows any significant association with the male and female labor demand indices. ${ }^{23}$ We also might be concerned that the male and female labor demand indices have differing associations with the composition of the NHIS sample. This would occur of the two indices had asymmetrical effects on marriage and divorce, migration (for example, if families are more likely to relocate in response to fathers' job opportunities), or survey nonresponse (for example, if maternal employment leads to a reduction in the likelihood of completing the survey). To address this issue, we estimate correlations between our male and female labor demand indices and indicators for child race, child gender, parents' marital status, and parents' educational attainment in our NHIS sample. These results, shown in Appendix Table A4, reassuringly suggest that our results are not driven by asymmetrical changes in sample composition associated with the male and female indices.

\footnotetext{
${ }^{23}$ It is worth noting that, as discussed in Section II, parents' mental health is a potential mechanism by which labor market conditions may affect child health. Thus, it would not be surprising if we were to find that male and female labor demand were each associated with significant changes in these outcomes. However, here we use these estimates in the spirit of a placebo test, with the idea that if the respondent's mental state were causing him or her to misreport a child's health, that it is likely that we would see this same pattern of misreporting in the respondent's own outcomes and in those of the other parent. As we find no consistent patterns in the effects of the male and female labor demand indices on parents' mental health outcomes, we are less worried about the possibility of differential misreporting.
} 
Finally, it may be that the male and female labor market indices are associated with different states of the aggregate economy. In particular, since male labor market conditions tend to suffer more in a recession than female labor market conditions (Hoynes, Miller, and Schaller, 2012), an increase in the male labor demand index, holding the female labor demand index constant, might be proxying for some unobservable factor associated with a weaker economy in general. We roughly test for this by including a control for the state unemployment rate in the regressions on the gender-specific indices. These results, presented in Appendix Table A5, show that the observed patterns in the effects of male and female labor demand conditions on child health hold, even when controlling for the underlying state of the economy.

\section{B. Mechanisms}

Our results echo those of recent studies that document differential impacts of individual maternal and paternal job loss on children's health and achievement (Schaller and Zerpa, 2015; Liu and Zhao, 2011; Kalil and Ziol-Guest, 2008). Our analyses differ from the previous research, however, because we focus on the impact of aggregate demand conditions, rather than individual job loss. As described in Section II, there are a number of reasons that the impacts of parental job loss may differ from the impacts of community-level employment opportunities. For example, some researchers have argued that because pollution moves counter-cyclically, it might contribute to the pro-cyclical variation in mortality. Our estimates are not consistent with pollution playing an important role, however, as men are more likely than women to be employed in industries that produce high levels of pollution. We find no evidence that male employment opportunities are associated with worse children's health outcomes - which suggests that pollution is unlikely to be a leading mechanism for our findings, at least in the short run. Similarly, it is unlikely that the estimates reflect variation in the provision of social services over the business cycle, as such variation would be tied to variation in tax revenues and should produce positive coefficients on both the male and female employment indices. Subgroup-specific regressions in which we stratify by child age (0-5, 6-17) and maternal education (high school or less, some college or more) do not yield any 
discernable patterns, or provide insights as to potential mechanisms (results of those analyses are provided in Tables B1 and B2 in an online appendix).

Another possibility is that the differential impacts of male and female employment opportunities on children's health reflect differences in how mothers' and fathers' own health, and health behaviors, vary with changes in labor market demand. For example, the probability that a child has an asthma attack might fall when male employment opportunities improve because working fathers may smoke less or smoke away from home more, but the reverse might be true for mothers. To investigate this possibility, we have estimated regressions in which we replace the child health outcomes with indicators of maternal and paternal health behaviors (smoking, drinking). We find no evidence that these potential pathways are driving our estimates: across the regressions there are no consistent patterns, and virtually none of the estimates are statistically significant. ${ }^{24}$

Our estimates do line up well with several well-known empirical facts. First, in most married couple households, husbands work more hours than wives, are more likely to be employed full time, and have higher wages. ${ }^{25}$ This suggests that compared to changes in women's labor market opportunities, improvements in men's opportunities should have larger effects on family income and health insurance coverage. To the extent that income and insurance coverage are associated with better child health, improvements in men's employment opportunities should therefore have a relatively larger positive effect. We investigate this hypothesis by estimating regressions with measures of insurance coverage and underutilization of healthcare as dependent variables. We examine the relationship between our male and female employment growth indices and 1) whether medical care was delayed in the past twelve months due to concerns about costs, 2) whether the child needed medical care in the past twelve months but did not get it due to costs, and 3) whether the child currently has no insurance coverage.

\footnotetext{
${ }^{24}$ Results for parents' mental health are shown in Appendix Table A3. Results for parents' smoking and drinking are shown in Table B3 in an online appendix.

${ }^{25}$ Recently Bertrand et al. (2015) documents that from 2008-2011, wives earn more than their husbands in only $27 \%$ of households.
} 
The results of this exercise are shown in Table 5. The pattern of estimates lines up well with our expectations: while the point estimates associated with the male and female employment indices in the first three columns are all negative (as expected), the estimates on the male index are substantively larger. Moreover, the estimated effects of predicted male employment growth on whether medical care was delayed due to costs, or whether the child did not get medical care due to costs, are both substantial and statistically different from zero. The estimated effect of a one percentage point increase in male employment growth is associated with a six to eight percent decline in the probability that a parent reports that his/her child's medical care is delayed due to costs, and a six to eight percent decline in the probability that a parent reports his/her child did not receive medical care due to costs. The pattern and relative magnitudes of the estimates are consistent with our expectations given that husbands are typically the primary earners in the household.

Another possible reason for differences between coefficients on the male and female indices is differences in time use and how it responds to labor market shocks. It is well known that employed women spend more time in housework and child care than employed men, even conditional on hours of paid work (e.g. Hartman et al., 2010). For example, among married parents who are full time workers, $71 \%$ of mothers spend some time caring for their children, whereas only $54 \%$ of fathers do so (BLS, 2008). Notably, recent research has found that among parents who have recently become unemployed, mothers are more likely than fathers to reallocate their time to parenting tasks (Aguiar et al., 2013; Lindo et al., 2013; Pailhé and Solaz, 2012). ${ }^{26}$ This suggests that if parental care is an important contributor to children's health, improvements in female labor market opportunities will have a relatively greater (negative) impact on children's health, which is consistent with our findings.

\footnotetext{
${ }^{26}$ For example, using the data from the American Time Use Survey, Aguiar et al. (2013) find that women reallocate nearly twice as many of their foregone market work hours in a recession to childcare as men do, and Lindo et al. (2013) find that maternal non-employment is associated with an 80 percent larger increase in minutes alone with children than paternal non-employment, controlling for employment status in an earlier period. While we did try to investigate the correlations between our key explanatory variables and parental time use using the ATUS, we found that the ATUS sample was both too short (it doesn't begin until 2003) and too small, in terms of numbers of observations per state, to generate precise estimates of these associations with our identification strategy. For similar reasons, we have estimated but do not to report associations between economic conditions and parental activity variables from the child welfare modules of the Survey of Income and Program Participation.
} 


\section{Conclusions}

This paper examines the link between labor market conditions and children's health. An extensive literature documents that adult health declines when labor market opportunities improve, but we know very little about the extent to which this relationship translates to children's health outcomes. Economic theory does not provide clear predictions about the sign of the relationship. Moreover, existing research hints that changes in labor demand for mothers and fathers may affect the production of children's health very differently.

We are among the first to examine the relationship between cyclical changes in labor market opportunities and children's health, and the first to address the potential endogeneity that is inherent in related empirical analyses that rely on common measures of employment opportunities, such as the unemployment rate. We do this by developing a predicted employment growth rate that exploits statespecific industry employment shares in a base period together with national, industry-specific, employment growth. We then take this approach to analyses of labor demand conditions and genderspecific influences on children's health.

Unlike most studies of adult health, we find no evidence that general labor demand conditions are associated with improvements in contemporaneous measures of children's health outcomes. Instead, we find that increases in local unemployment rates are associated with small but significant increases in the incidence of injuries and severe emotional difficulties among children. This empirical result also contrasts with previous studies that have documented a negative correlation between the unemployment rate and infant health outcomes.

We also find consistent evidence that focusing on a broad measure of employment opportunities masks important underlying relationships. Specifically, we find that improvements in male labor market conditions are associated with decreases in injuries among children, while improvements in labor market conditions facing women are associated with declining parent-reported child health and increases in the likelihood that children experience severe emotional difficulties. One possible interpretation of these 
patterns is that mothers and fathers typically provide different inputs into the production of children's health, with mothers making relatively larger time investments and fathers providing higher levels of monetary support. 


\section{References}

Aguiar, Mark, Erik Hurst, and Loukas Karabarbounis, 2013. "Time Use During the Great Recession," American Economic Review, 103(5): 1664-96.

Aizer, Anna, 2010. "The Gender Wage Gap and Domestic Violence," American Economic Review, 100(4): 1847-1859.

Almond, Douglas, and Janet Currie, 2011. "Human Capital Development Before Age Five," In Handbook of Labor Economics, Vol. 4B, edited by Orley Ashenfelter and David E. Card, 1315-1486. Amsterdam: Elsevier.

Anderson, Patricia M., Kristin F. Butcher, and Phillip B. Levine, 2003 "Maternal Employment and Overweight Children," Journal of Health Economics, 22(3): 477-504

Anderson, Michael, 2008. "Multiple Inference and Gender Differences in the Effects of Early Intervention: A Reevaluation of the Abecedarian Perry Preschool," Journal of the American Statistical Association, 103(484): 1481-1495.

Bartik, Timothy J., 1991. Who Benefits from State and Local Economic Development Policies? W.E. Upjohn Institute for Employment Research.

Bertrand, Marianne, Emir Kamenica, and Jessica Pan, 2015. "Gender Identity and Relative Income within Households," The Quarterly Journal of Economics, 130(2): 571-614.

Blanchard, Olivier Jean, and Lawrence F. Katz, 1992. "Regional Evolutions," Brookings Papers on Economic Activity, 1992(1): 1-75.

Blanchflower, David G., and Andrew J. Oswald, 2004. "Well-being Over Time in Britain and the USA," Journal of Public Economics, 88(7-8): 1359-1386.

Bradford, W. David, and William D. Lastrapes, 2014. "A Prescription for Unemployment? Recessions and the Demand for Mental Health Drugs," Health Economics, 23(11):1301-1325.

Brand, Jennie E., Becca R. Levy, and William T. Gallo, 2008. "Effects of Layoffs and Plant Closings on Subsequent Depression Among Older Workers," Research on Aging, 30(6):701-721.

Browning, Martin, and Eskil Heinesen, 2012. "Effect of Job Loss due to Plant Closure on Mortality and Hospitalization," Journal of Health Economics, 31(4): 599-616.

Bryant, W. Keith, and Cathleen D. Zick, 1993. "Trends in Time Spent Caring for Children: 1924:31 vs. 1981. Proceedings of the American Statistical Association's 1993 Winter Conference, 401-409.

Case, Anne, Darren Lubotsky, and Christina Paxson, 2002. "Economic Status and Health in Childhood: The Origins of the Gradient," American Economic Review, 92(5): 1308-1334.

Cawley, John, Asako S. Moriya, and Kosali Simon, 2015. "The Impact of the Macroeconomy on Health Insurance Coverage: Evidence from the Great Recession," Health Economics, 24(2):206-223.

Chay, Kenneth, and Michael Greenstone, 2003. "The Impact of Air Pollution on Infant Mortality: Evidence from Geographic Variation in Pollution Shocks Induced by a Recession," The Quarterly Journal of Economics, 118(3): 1121-67.

Conger, Rand D., Xiaojia Ge, Glen H. Elder, Frederick O. Lorenz, and Ronald L. Simons, 1994. "Economic Stress, Coercive Family Process, and Developmental Problems of Adolescents," Child Development, 65(2): 541-561.

Conger, Rand D., and Kathrine J. Conger, 2007. "Understanding the Processes through which Economic Hardship Influences Families and Children." In R. Crane and E. Marshall (Eds.), Handbook of Families and Poverty: Interdisciplinary Perspectives, 64-81. 
Currie, Janet, and Matthew Neidell, 2005. "Air Pollution and Infant Health: What Can We Learn from California's Recent Experience?” The Quarterly Journal of Economics, 120(3): 1003-1030.

Currie, Janet, and Matthew Neidell and Johannes Schmieder, 2009. "Air Pollution and Infant Health: Lessons from New Jersey," Journal of Health Economics, 28(3): 688-703.

Currie, Janet, and Johannes F. Schmieder, 2009. "Fetal Exposures to Toxic Releases and Infant Health," American Economic Review, 99(2): 177-83.

Currie, Janet, and Reed Walker. 2011. "Traffic Congestion and Infant Health: Evidence from E-ZPass," American Economic Journal: Applied Economics, 3(1): 65-90.

Dehejia, Rajeev, and Adriana Lleras-Muney, 2004. “Booms, Busts, and Babies' Health,” The Quarterly Journal of Economics, 119(3): 1091-1130.

Dooley, David, and Catalano, R., 1984. “The Epidemiology of Economic Stress," American Journal of Community Psychology, 12(4): 387-409.

Dooley, David, Ralph Catalano and Karen S. Rook, 1988. "Personal and Aggregate Unemployment and Psychological Symptoms," Journal of Social Issues, 44(4): 107-123.

Evans, Williams, and John D. Graham, 1988. "Traffic Safety and the Business Cycle." Alcohol, Drugs, and Driving, 4(1): 31-38.

Fenwick, Rudy, and Mark Tausig, 1994. “The Macroeconomic Context of Job Stress," Journal of Health and Social Behavior, 35(3): 266-282.

Freeman, Richard B., 1999. "The Economics of Crime.” In Handbook of Labor Economics, Vol. 3C, edited by Orley Ashenfelter and David E. Card, 3529-3571. Amsterdam: Elsevier.

Gennetian, Lisa A., Heather D. Hill, Andrew S. London, and Leonard M. Lopoo, 2010. "Maternal Employment and the Health of Low-Income Young Children." Journal of Health Economics, 29(3): 353-63.

Grossman, Michael, 1972. "On the Concept of Health Capital and the Demand for Health." Journal of Political Economy, 80(2): 223-255.

Gruber, Jonathan, and Michael Frakes, 2006. “Does Falling Smoking Lead to Rising Obesity?” Journal of Health Economics, 25(2): 183-197.

Guryan, Jonathan, Erik Hurst, and Melissa Kearney, 2008. "Parental Education and Parental Time with Children," Journal of Economic Perspectives, 22(3): 23-46.

Hoynes, Hilary, Douglas L. Miller, and Jessamyn Schaller, 2012. "Who Suffers During Recessions?” The Journal of Economic Perspectives, 26(3): 27-47.

Institute of Medicine (US), 2000. Committee on the Assessment of Asthma and Indoor Air. Clearing the air: asthma and indoor air exposures. National Academy Press.

Kalil, Ariel and K. Ziol-Guest, 2008. "Parental Employment Circumstances and Children's Academic Progress," Social Science Research 37(2):500-515.

Kalil, Ariel, and K. Ziol-Guest, 2013 “The Great Recession and Married Parents' Use of Time.” mimeo.

Katz, Lawrence F, and Kevin M Murphy, 1992. "Changes in Relative Wages, 1963-1987: Supply and Demand Factors." The Quarterly Journal of Economics, 107(1): 35-78.

Kling, Jeffrey, Jeffrey Liebman and Lawrence Katz, 2007. "Experimental Analysis of Neighborhood Effects," Econometrica, 75(1): 83-119.

Knittel, Christopher R., Douglas L. Miller, Nicholas J. Sanders, 2011. “Caution, Drivers! Children 
Present: Traffic, Pollution, and Infant Health," National Bureau of Economic Research, Working Paper 17222.

Lindo, Jason M., 2015. "Aggregation and The Estimated Effects of Local Economic Conditions on Health," Journal of Health Economics, 40:83-96.

__ 2011. "Parental Job Loss and Infant Health.” Journal of Health Economics 30(5): 869-79.

Lindo, Jason M., Jessamyn Schaller, and Benjamin Hansen, 2013. "Economic Conditions and Child Abuse," National Bureau of Economic Research, Working Paper 18994.

Liu, Hong, and Zhao, Zhong, 2014. "Parental Job Loss and Children's Health: Ten Years After the Massive Layoff of the SOEs' Workers in China." China Economic Review, 31(C): 303-319.

Mork, Eva, Anna Sjogren, and Helena Svaleryd, 2014. "Parental Unemployment and Child Health." CESifo Economic Studies.

Morrill, Melinda S., 2011. "The Effects of Maternal Employment on the Health of School-age Children." Journal of Health Economics, 30 (2): 240-257.

Morrill, Melinda S., and Pabilonia, Sabrina W., 2015 "What Effects Do Macroeconomic Conditions have on the Time Couples with Children Spend Together?" Review of Economics of the Household, 1-24.

Morrissey, Taryn, Rachel E. Dunifon, and Ariel Kalil, 2011. "Maternal Employment, Work Schedules, and Children's Body Mass Index," Child Development, 82(1): 66-81.

National Center for Health Statistics, 2009. "2008 National Health Interview Survey (NHIS) Public Use Data Release, NHIS Survey Description."

Pailhé, Ariane, and Anne Solaz, 2012. "The Influence of Employment Uncertainty on Childbearing in France: A Tempo or Quantum Effect?” Demographic Research, 26(1): 1-40.

Phipps, Shelley A., Lynn Lethbridge, and Peter Burton, 2006. "Long-run Consequences of Parental Paid Work Hours for Child Overweight Status in Canada," Social Science and Medicine, 62(4):977-986.

Pleck, Joseph H., 1997. "Paternal Involvement: Levels, Sources, and Consequences." In The role of the father in child development, Vol. 14 ( $3^{\text {rd }}$ edition), edited by M. E. Lamb. 14: 66-103. New York: John Wiley \& Sons.

Ruhm, Christopher J., 2000. “Are Recessions Good For Your Health?” The Quarterly Journal of Economics, 115( 2): 617-650.

__ 2003. “Good Times Make You Sick.” Journal of Health Economic,s 22(4): 637-58.

__ 2005a. "Mortality Increases During Economic Upturns.” International Journal of Epidemiology, 34(6): 1206-1211.

—_, 2005b. "Healthy Living in Hard Times." Journal of Health Economics, 24(2): 341-63. , 2015. “Recessions, Healthy No More?” Journal of Health Economics, 42(C): 17-28.

Ruhm, Christopher, and William E. Black, 2002. "Does Drinking Really Decrease in Bad Times?" Journal of Health Economics, 21(4): 659-678.

Sabia, Joseph J, 2008. "Every Breath You Take: The Effect of Postpartum Maternal Smoking On Childhood Asthma." Southern Economic Journal, 75(1): 128-158.

Sanders, Nicholas J., 2012. “What Doesn't Kill You Makes You Weaker: Prenatal Pollution Exposure and Educational Outcomes." Journal of Human Resources, 47(3): 826-850.

Schaller, Jessamyn, 2016. “Booms, Busts, and Fertility: Testing the Becker Model Using Gender- 
Specific Labor Demand." Journal of Human Resources, 51(1): 1-29.

Schaller, Jessamyn, and Mariana Zerpa, 2015. "Short-run Effects of Parental Job Loss on Child Health." National Bureau of Economic Research, Working Paper 21745.

Schaller, Jessamyn, and Ann H. Stevens, 2015. "Short-Run Effects of Job Loss on Health Conditions, Health Insurance, and Health Care Utilization.” Journal of Health Economics, 43: 190-203.

Shankardass, Ketan, Rob McConnell, Michael Jerrett, Joel Milam, Jean Richardson, and Kiros Berhane, 2009. "Parental Stress Increases the Effect of Traffic-Related Air Pollution on Childhood Asthma Incidence." Proceedings of the National Acadamy of Sciences, 106 (30) 12406-12411.

Soni, Anita, 2014. "STATISTICAL BRIEF \#434: The Five Most Costly Children's Conditions, 2011: Estimates for U.S. Civilian Noninstitutionalized Children, Ages 0-17.” Agency for Healthcare Research and Quality. Accessed May 19, 2015. http://meps.ahrq.gov/data_files/publications/st434/stat434.shtml.

Stevens, Ann Huff, Douglas L. Miller, Marianne E. Page, and Mateusz Filipski, 2015. "The Best of Times, the Worst of Times: Understanding Pro-Cyclical Mortality." American Economic Journal: Economic Policy, 7(4): 279-311.

Xu, Xin, 2013. "The Business Cycle and Child Health Behaviors," Social Science and Medicine, 77:126136. 
Table 1. Summary Statistics

\begin{tabular}{|c|c|c|c|}
\hline Variable & Mean & Observations & Dataset \\
\hline \multicolumn{4}{|l|}{ Outcomes } \\
\hline Costly Conditions Index & $\begin{array}{c}-0.002 \\
(0.518)\end{array}$ & 105574 & Child file \\
\hline Fair/Poor Health & $\begin{array}{c}1.840 \\
(13.439)\end{array}$ & 409983 & Person file \\
\hline Excellent Health & $\begin{array}{c}54.960 \\
(49.753)\end{array}$ & 409983 & Person file \\
\hline Sick Days from School & $\begin{array}{c}3.522 \\
(6.553)\end{array}$ & 134191 & Child file \\
\hline Child Asthma (past 12 months) & $\begin{array}{c}5.474 \\
(22.748)\end{array}$ & 194000 & Child file \\
\hline Ear Infection & $\begin{array}{c}6.110 \\
(23.952)\end{array}$ & 193102 & Child file \\
\hline Severe Emotional Difficulties & $\begin{array}{c}1.210 \\
(10.934)\end{array}$ & 105681 & Child file \\
\hline Number of Injuries & $\begin{array}{c}2.292 \\
(15.701)\end{array}$ & 410959 & Person file \\
\hline \multicolumn{4}{|l|}{ Demographic } \\
\hline Child Age & $\begin{array}{c}8.525 \\
(5.185)\end{array}$ & 410959 & Person file \\
\hline$\%$ Mothers HS Dropout & $\begin{array}{c}13.922 \\
(34.618)\end{array}$ & 410959 & Person file \\
\hline$\%$ Mothers HS Grad & $\begin{array}{c}22.582 \\
(41.812)\end{array}$ & 410959 & Person file \\
\hline$\%$ Mothers Some College & $\begin{array}{c}40.645 \\
(50.000)\end{array}$ & 410959 & Person file \\
\hline$\%$ Married & $\begin{array}{c}69.793 \\
(45.915)\end{array}$ & 410959 & Person file \\
\hline \multicolumn{4}{|l|}{$\underline{\text { Economic Conditions }}$} \\
\hline Unemployment Rate & $\begin{array}{c}5.570 \\
(2.023)\end{array}$ & 410959 & \\
\hline Female Labor Demand Index & $\begin{array}{c}0.940 \\
(1.251)\end{array}$ & 410959 & \\
\hline Male Labor Demand Index & $\begin{array}{c}0.362 \\
(1.927)\end{array}$ & 410959 & \\
\hline Total Index & $\begin{array}{c}0.628 \\
(1.565) \\
\end{array}$ & 410959 & \\
\hline
\end{tabular}

Notes: The data are from the 1997-2012 Person and Child Files of the National Health Interview Survey. State monthly unemployment rates are from the Bureau of Labor Statistics. Labor demand indices, described in detail in Section IV, are created using data from the decennial Census and Current Population Surveys. 
Table 2: The Effect of the Unemployment Rate on Child Health

\begin{tabular}{|c|c|c|c|c|}
\hline Outcome & $\begin{array}{c}\text { Dependen } \\
\text { Variable } \\
\text { Mean }\end{array}$ & Model 1 & Model 2 & Model 3 \\
\hline \multicolumn{5}{|c|}{ General Measures of Child Health } \\
\hline$\frac{\text { Costly Conditions Index }}{N=105574}$ & -0.002 & $\begin{array}{l}0.006^{* *} \\
(0.002)\end{array}$ & $\begin{array}{l}0.006^{*} \\
(0.003)\end{array}$ & $\begin{array}{l}0.005 \\
(0.004)\end{array}$ \\
\hline$\frac{\text { Fair/Poor Health }}{N=409983}$ & 1.840 & $\begin{array}{c}0.058 \\
(0.036)\end{array}$ & $\begin{array}{c}0.056 \\
(0.043)\end{array}$ & $\begin{array}{c}0.021 \\
(0.062)\end{array}$ \\
\hline$\frac{\text { Excellent Health }}{N=409983}$ & 54.960 & $\begin{array}{l}-0.427 \\
(0.336)\end{array}$ & $\begin{array}{l}-0.461 \\
(0.309)\end{array}$ & $\begin{array}{l}-0.646 \\
(0.451)\end{array}$ \\
\hline$\frac{\text { Sick Days from School }}{N=134191}$ & 3.522 & $\begin{array}{c}0.027 \\
(0.033)\end{array}$ & $\begin{array}{c}0.037 \\
(0.039)\end{array}$ & $\begin{array}{c}0.058 \\
(0.048)\end{array}$ \\
\hline \multicolumn{5}{|c|}{ Specific Child Health Outcomes } \\
\hline$\frac{\text { Asthma Attack in } 12 \text { months }}{N=194000}$ & 5.474 & $\begin{array}{c}0.072 \\
(0.088)\end{array}$ & $\begin{array}{c}0.084 \\
(0.087)\end{array}$ & $\begin{array}{l}-0.033 \\
(0.111)\end{array}$ \\
\hline$\frac{\text { Ear Infections }}{N=193102}$ & 6.111 & $\begin{array}{c}0.030 \\
(0.099)\end{array}$ & $\begin{array}{c}0.122 \\
(0.101)\end{array}$ & $\begin{array}{l}0.035 \\
(0.132)\end{array}$ \\
\hline$\frac{\text { Severe Emotional Difficulties }}{N=105681}$ & 1.210 & $\begin{array}{l}0.131^{* *} \\
(0.042)\end{array}$ & $\begin{array}{r}0.124 * * \\
(0.057)\end{array}$ & $\begin{array}{l}0.139^{*} \\
(0.072)\end{array}$ \\
\hline$\frac{\text { Number of Injuries }}{N=410959}$ & 2.292 & $\begin{array}{l}0.141^{* *} \\
(0.044)\end{array}$ & $\begin{array}{l}0.120^{* *} \\
(0.046)\end{array}$ & $\begin{array}{l}0.120^{*} \\
(0.063)\end{array}$ \\
\hline $\begin{array}{l}\text { State and Age-Year FE } \\
\text { State-Year Controls } \\
\text { State Trends }\end{array}$ & & $\begin{array}{l}\text { Yes } \\
\text { No } \\
\text { No }\end{array}$ & $\begin{array}{l}\text { Yes } \\
\text { Yes } \\
\text { No }\end{array}$ & $\begin{array}{l}\text { Yes } \\
\text { Yes } \\
\text { Yes }\end{array}$ \\
\hline
\end{tabular}

Notes: Standard errors (in parentheses) are clustered at the state level. Health data are from the 1997-2012 Person and Child Files of the National Health Interview Survey. State monthly unemployment rates are from the Bureau of Labor Statistics. Individual control variables include parents' marital status, child race, child gender, and mother's education. State control variables include the state average home price, the number of births, the fraction of the population in each of three education groups, and the fraction of the population in each of three race groups in a given year. ${ }^{*} \mathrm{p}<0.10,{ }^{* *} \mathrm{p}<0.05,{ }^{* * *} \mathrm{p}<0.01$. 
Table 3: The Effect of the Predicted Employment Growth Rate on Child Health

\begin{tabular}{lcccc} 
Outcome & $\begin{array}{c}\text { Dependent } \\
\text { Variable } \\
\text { Mean }\end{array}$ & Model 1 & Model 2 & Model 3 \\
\hline \hline \multicolumn{1}{c}{ General Measures of Child Health } & & \\
Costly Conditions Index & -0.002 & 0.0002 & 0.0004 & 0.0011 \\
$N=105574$ & & $(0.0036)$ & $(0.0037)$ & $(0.0038)$ \\
Fair/Poor Health & 1.840 & 0.047 & 0.043 & 0.060 \\
$N=409983$ & & $(0.048)$ & $(0.050)$ & $(0.051)$ \\
Excellent Health & 54.960 & -0.401 & -0.354 & -0.386 \\
$N=409983$ & & $(0.331)$ & $(0.339)$ & $(0.338)$ \\
$\frac{\text { Sick Days from School }}{N=134191}$ & 3.522 & 0.042 & 0.037 & 0.036 \\
& & $(0.039)$ & $(0.039)$ & $(0.039)$
\end{tabular}

\section{Specific Child Health Outcomes}

\begin{tabular}{|c|c|c|c|c|}
\hline $\begin{array}{l}\text { Asthma Attack in } 12 \text { months } \\
N=194000\end{array}$ & 5.474 & $\begin{array}{l}-0.123 \\
(0.139)\end{array}$ & $\begin{array}{l}-0.154 \\
(0.140)\end{array}$ & $\begin{array}{l}-0.134 \\
(0.140)\end{array}$ \\
\hline$\frac{\text { Ear Infections }}{N=193102}$ & 6.111 & $\begin{array}{c}0.062 \\
(0.169)\end{array}$ & $\begin{array}{c}0.048 \\
(0.163)\end{array}$ & $\begin{array}{c}0.064 \\
(0.160)\end{array}$ \\
\hline$\frac{\text { Severe Emotional Difficulties }}{N=105681}$ & 1.210 & $\begin{array}{c}0.110 \\
(0.080)\end{array}$ & $\begin{array}{c}0.109 \\
(0.080)\end{array}$ & $\begin{array}{c}0.116 \\
(0.082)\end{array}$ \\
\hline$\frac{\text { Number of Injuries }}{N=410959}$ & 2.292 & $\begin{array}{l}-0.021 \\
(0.058)\end{array}$ & $\begin{array}{l}-0.020 \\
(0.059)\end{array}$ & $\begin{array}{l}-0.008 \\
(0.060)\end{array}$ \\
\hline $\begin{array}{l}\text { State and Age-Year FE } \\
\text { State-Year Controls } \\
\text { State Trends }\end{array}$ & & $\begin{array}{l}\text { Yes } \\
\text { No } \\
\text { No }\end{array}$ & $\begin{array}{l}\text { Yes } \\
\text { Yes } \\
\text { No }\end{array}$ & $\begin{array}{l}\text { Yes } \\
\text { Yes } \\
\text { Yes }\end{array}$ \\
\hline \multicolumn{5}{|c|}{$\begin{array}{l}\text { Notes: Here, unlike in Table } 2 \text {, an increase in the explanatory variable represents } \\
\text { improvement in economic conditions rather than deterioration. Standard errors (in } \\
\text { parentheses) are clustered at the state level. Health data are from the } 1997-2012 \text { Person } \\
\text { and Child Files of the National Health Interview Survey. Labor demand indices, } \\
\text { described in detail in Section IV, are created using data from the decennial Census and } \\
\text { Current Population Surveys. Individual control variables include parents' marital status, } \\
\text { child race, child gender, and mother's education. State control variables include the state } \\
\text { average home price, the number of births, the fraction of the population in each of three } \\
\text { education groups, and the fraction of the population in each of three race groups in a } \\
\text { given year. }{ }^{*} p<0.10,{ }^{* *} p<0.05, * * * p<0.01 \text {. }\end{array}$} \\
\hline
\end{tabular}


Table 4: The Effect of Male and Female Predicted Employment Growth Rates on Child Health

\section{General Measures of Child Health}

\section{Specific Child Health Outcomes}

Model $1 \quad$ Model $2 \quad$ Model 3

Model $1 \quad$ Model $2 \quad$ Model 3

Dependent Variable: Costly Conditions Index

Predicted Male $\quad-0.009 * *-0.009 * * \quad-0.008 *$

Employment Growth $\quad(0.004) \quad(0.004) \quad(0.004) \quad$ Employment Growth $\quad(0.139) \quad(0.140) \quad(0.138)$

$\begin{array}{llllllll}\text { Predicted Female } & 0.015^{* *} & 0.015^{* *} & 0.012 * * & \text { Predicted Female } & 0.236 & 0.221 & 0.225\end{array}$

Employment Growth $\quad(0.005) \quad(0.005) \quad(0.006) \quad$ Employment Growth $\quad(0.167) \quad(0.166) \quad(0.159)$

Dependent Variable: Fair/Poor Health

$\begin{array}{lccclcccc}\text { Predicted Male } & -0.027 & -0.033 & -0.006 & & \text { Predicted Male } & -0.050 & -0.092 & -0.069 \\ \text { Employment Growth } & (0.060) & (0.064) & (0.065) & \text { Employment Growth } & (0.149) & (0.143) & (0.140) \\ & & & & & & & & \\ & & & & & & & & \\ \text { Predicted Female } & 0.102 & 0.105 & 0.085 & \text { Predicted Female } & 0.154 & 0.198 & 0.182 \\ \text { Employment Growth } & (0.067) & (0.069) & (0.072) & \text { Employment Growth } & (0.198) & (0.196) & (0.194)\end{array}$

Dependent Variable: Excellent Health

$\begin{array}{lccclcccc}\text { Predicted Male } & 0.142 & 0.212 & 0.208 & & \text { Predicted Male } & -0.023 & -0.023 & -0.020 \\ \text { Employment Growth } & (0.358) & (0.377) & (0.393) & \text { Employment Growth } & (0.084) & (0.086) & (0.090) \\ & & & & & & & & \\ & & & & & & & & \\ \text { Predicted Female } & -0.740^{* *} & -0.782^{* *} & -0.809^{*} & \text { Predicted Female } & 0.176^{*} & 0.175^{*} & 0.176 \\ \text { Employment Growth } & (0.348) & (0.372) & (0.404) & \text { Employment Growth } & (0.102) & (0.104) & (0.108)\end{array}$

Dependent Variable: Sick Days

$\begin{array}{lccclllll}\text { Predicted Male } & -0.049 & -0.053 & -0.062 & \text { Predicted Male } & -0.123^{* *} & -0.121^{*} & -0.090 \\ \text { Employment Growth } & (0.042) & (0.045) & (0.043) & \text { Employment Growth } & (0.060) & (0.063) & (0.068) \\ & & & & & & & & \\ & & & & & & & \\ \text { Predicted Female } & 0.126^{*} & 0.125^{*} & 0.137^{* *} & \text { Predicted Female } & 0.157^{*} & 0.155^{*} & 0.121 \\ \text { Employment Growth } & (0.067) & (0.071) & (0.067) & \text { Employment Growth } & (0.080) & (0.082) & (0.085)\end{array}$

\begin{tabular}{llllllll}
\hline State and Age-Year FE & Yes & Yes & Yes & State and Age-Year FE & Yes & Yes & Yes \\
State-Year Controls & No & Yes & Yes & State-Year Controls & No & Yes & Yes \\
State Trends & No & No & Yes & State Trends & No & No & Yes \\
\hline \hline
\end{tabular}

Notes: Standard errors (in parentheses) are clustered at the state level. Health data are from the 1997-2012 Person and Child Files of the National Health Interview Survey. Labor demand indices, described in detail in Section IV, are created using data from the decennial Census and Current Population Surveys. Individual control variables include parents' marital status, child race, child gender, and mother's education. State control variables include the state average home price, the number of births, the fraction of the population in each of three education groups, and the fraction of the population in each of three race groups in a given year. ${ }^{*} \mathrm{p}<0.10$, $* * \mathrm{p}<0.05, * * * \mathrm{p}<0.01$. 
Table 5: The Effect of Male and Female Predicted Employment Growth Rates on Child Insurance and Health Care Use

\begin{tabular}{|c|c|c|c|c|}
\hline Outcome & $\begin{array}{l}\text { Dependent } \\
\text { Variable } \\
\text { Mean } \\
\end{array}$ & Model 1 & Model 2 & Model 3 \\
\hline \multicolumn{5}{|l|}{ Delayed Medical Care } \\
\hline $\begin{array}{l}\text { Predicted Male } \\
\text { Employment Growth }\end{array}$ & 3.780 & $\begin{array}{l}-0.249 * \\
(0.132)\end{array}$ & $\begin{array}{c}-0.305 * * \\
(0.140)\end{array}$ & $\begin{array}{l}-0.224^{*} \\
(0.130)\end{array}$ \\
\hline $\begin{array}{l}\text { Predicted Female } \\
\text { Employment Growth }\end{array}$ & & $\begin{array}{l}-0.141 \\
(0.180)\end{array}$ & $\begin{array}{l}-0.085 \\
(0.193)\end{array}$ & $\begin{array}{l}-0.167 \\
(0.181)\end{array}$ \\
\hline \multicolumn{5}{|c|}{ Needed Medical Care, not get it due to the costs } \\
\hline $\begin{array}{l}\text { Predicted Male } \\
\text { Employment Growth }\end{array}$ & 2.240 & $\begin{array}{l}-0.144 * \\
(0.075)\end{array}$ & $\begin{array}{c}-0.173 * * \\
(0.069)\end{array}$ & $\begin{array}{l}-0.128 * \\
(0.069)\end{array}$ \\
\hline $\begin{array}{l}\text { Predicted Female } \\
\text { Employment Growth }\end{array}$ & & $\begin{array}{l}-0.058 \\
(0.084)\end{array}$ & $\begin{array}{l}-0.030 \\
(0.092)\end{array}$ & $\begin{array}{l}-0.075 \\
(0.091)\end{array}$ \\
\hline \multicolumn{5}{|l|}{ No Insurance Coverage } \\
\hline $\begin{array}{l}\text { Predicted Male } \\
\text { Employment Growth }\end{array}$ & 9.480 & $\begin{array}{l}-0.237 \\
(0.200)\end{array}$ & $\begin{array}{l}-0.202 \\
(0.196)\end{array}$ & $\begin{array}{l}-0.169 \\
(0.192)\end{array}$ \\
\hline $\begin{array}{l}\text { Predicted Female } \\
\text { Employment Growth }\end{array}$ & & $\begin{array}{l}-0.006 \\
(0.198)\end{array}$ & $\begin{array}{l}-0.065 \\
(0.200)\end{array}$ & $\begin{array}{l}-0.010 \\
(0.190)\end{array}$ \\
\hline $\begin{array}{l}\text { State and Age-Year FE } \\
\text { State-Year Controls } \\
\text { State Trends }\end{array}$ & & $\begin{array}{l}\text { Yes } \\
\text { No } \\
\text { No } \\
\end{array}$ & $\begin{array}{l}\text { Yes } \\
\text { Yes } \\
\text { No } \\
\end{array}$ & $\begin{array}{l}\text { Yes } \\
\text { Yes } \\
\text { Yes } \\
\end{array}$ \\
\hline \multicolumn{5}{|c|}{$\begin{array}{l}\text { Notes: Standard errors (in parentheses) are clustered at the state level. Health utilization } \\
\text { and insurance data are from the 1997-2012 Person and Child Files of the National Health } \\
\text { Interview Survey. Labor demand indices, described in detail in Section IV, are created } \\
\text { using data from the decennial Census and Current Population Surveys. State control } \\
\text { variables include the state average home price, the number of births, the fraction of the } \\
\text { population in each of three education groups, and the fraction of the population in each of } \\
\text { three race groups in a given year. }{ }^{*} \mathrm{p}<0.10,{ }^{* *} \mathrm{p}<0.05,{ }^{* * *} \mathrm{p}<0.01 \text {. }\end{array}$} \\
\hline
\end{tabular}




\section{Appendix A}

Figure A1: Average Predicted Employment Growth Rate and Unemployment Rate, 1997-2012

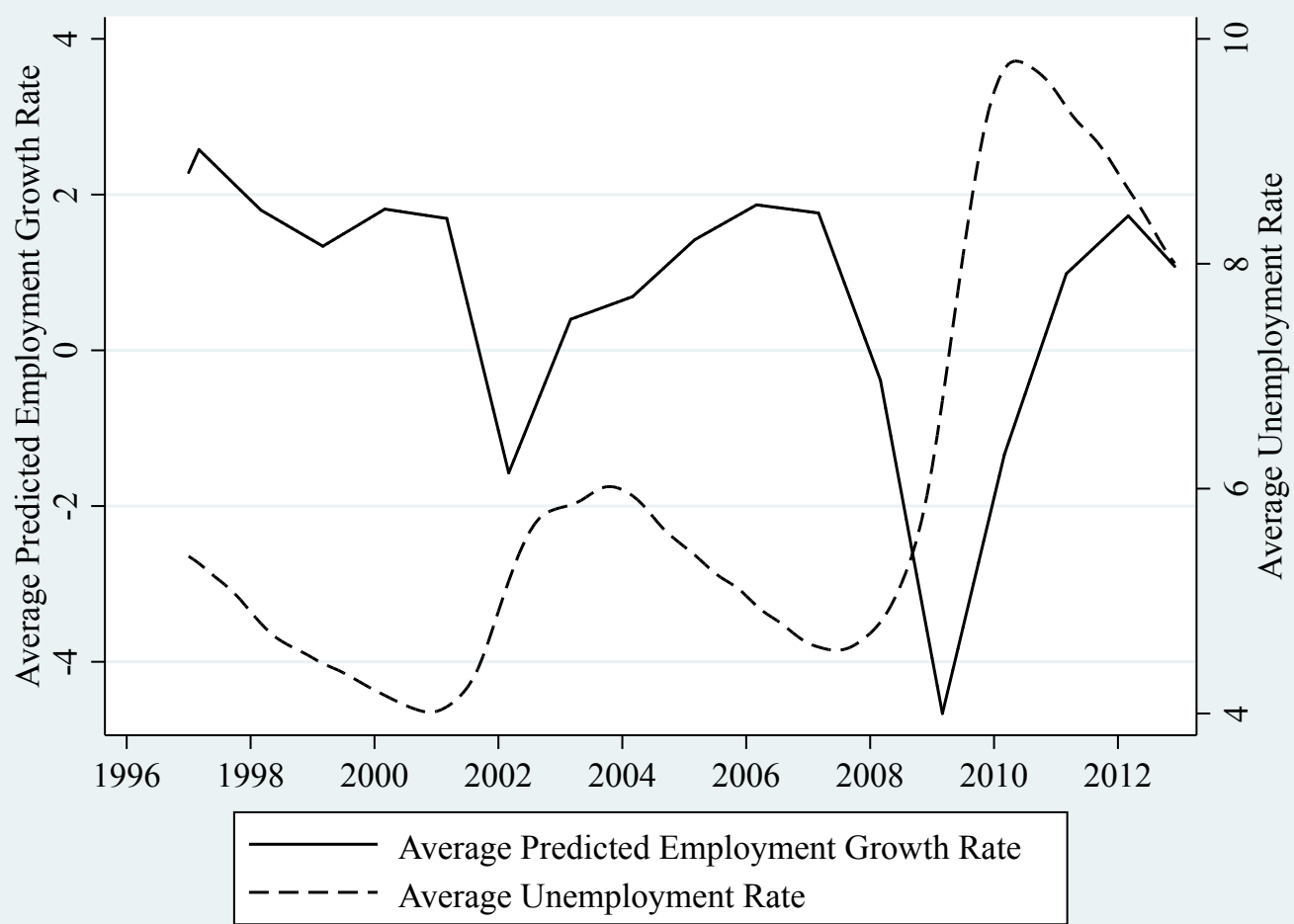

Notes: The predicted employment growth rate and the unemployment rate shown above are population-weighted averages of state-specific values in each month. In addition to being averages across states, both variables represent economic conditions averaged over the last 12 months, to match the explanatory variables in our regressions. The predicted employment growth rate is a weighted average of two adjacent March-March values, depending on the month in question, as described in Section IV. The unemployment rate is averaged over the 12months prior, as described in Section III. 
Table A1: Estimated Relationships Between Measures of Predicted Employment Growth and Labor Market Conditions

\section{Female Outcomes}

\begin{tabular}{lccc} 
& $\begin{array}{c}\text { Employment } \\
\text { Growth Rate } \\
(12 \mathrm{mo})\end{array}$ & $\begin{array}{c}\text { Employment } \\
\text { Rate }\end{array}$ & $\begin{array}{c}\text { Unemployment } \\
\text { Rate }\end{array}$ \\
\hline Predicted Male & -0.037 & -0.024 & $-0.129^{*}$ \\
Employment Growth & $(0.203)$ & $(0.098)$ & $(0.065)$ \\
Predicted Female & $0.671^{* *}$ & 0.141 & -0.071 \\
Employment Growth & $(0.291)$ & $(0.098)$ & $(0.081)$ \\
\hline Sample Mean & 1.243 & 68.671 & 5.637 \\
\hline \hline
\end{tabular}

\section{Male Outcomes}

\begin{tabular}{lccc} 
& $\begin{array}{c}\text { Employment } \\
\text { Growth Rate } \\
(12 \mathrm{mo})\end{array}$ & $\begin{array}{c}\text { Employment } \\
\text { Rate }\end{array}$ & $\begin{array}{c}\text { Unemployment } \\
\text { Rate }\end{array}$ \\
\hline Predicted Male & $\begin{array}{c}0.539^{* *} \\
(0.221)\end{array}$ & $\begin{array}{c}0.363^{* * *} \\
(0.098)\end{array}$ & $\begin{array}{c}-0.465^{* * *} \\
(0.059)\end{array}$ \\
Employment Growth & 0.396 & -0.06 & 0.092 \\
Predicted Female & $(0.388)$ & $(0.133)$ & $(0.066)$ \\
Employment Growth & 0.834 & 79.498 & 6.104 \\
\hline Sample Mean & 0.496
\end{tabular}

Notes: Standard errors (in parentheses) are clustered at the state level. State-year measures of the employment growth rate, employment rate and unemployment rate are from the Current Population Surveys Monthly Ongoing Rotation Files. Labor demand indices, described in detail in Section IV, are created using data from the decennial Census and Current Population Surveys. State control variables include the state average home price, the number of births, the fraction of the population in each of three education groups, and the fraction of the population in each of three race groups in a given year. ${ }^{*} \mathrm{p}<0.10,{ }^{* *} \mathrm{p}<0.05,{ }^{* * *} \mathrm{p}<0.01$. 
Table A2: The Effect of the Unemployment Rate on Child Health - Including Lagged Unemployment Rate

General Measures of Child Health

Specific Child Health Outcomes

Model $1 \quad$ Model 2 Model 3

Model 1 Model 2 Model 3

\begin{tabular}{|c|c|c|c|c|c|c|c|}
\hline \multicolumn{4}{|c|}{ Dependent Variable: Costly Conditions Index } & \multicolumn{4}{|c|}{ Dependent Variable: Asthma } \\
\hline Unemployment Rate & $\begin{array}{c}0.004 \\
(0.003)\end{array}$ & $\begin{array}{c}0.004 \\
(0.004)\end{array}$ & $\begin{array}{c}0.004 \\
(0.004)\end{array}$ & Unemployment Rate & $\begin{array}{l}-0.102 \\
(0.140)\end{array}$ & $\begin{array}{l}-0.054 \\
(0.133)\end{array}$ & $\begin{array}{l}-0.102 \\
(0.135)\end{array}$ \\
\hline $\begin{array}{l}\text { Lagged Unemployment } \\
\text { Rate }\end{array}$ & $\begin{array}{c}0.003 \\
(0.003)\end{array}$ & $\begin{array}{c}0.004 \\
(0.004)\end{array}$ & $\begin{array}{c}0.002 \\
(0.004)\end{array}$ & $\begin{array}{l}\text { Lagged Unemployment } \\
\text { Rate }\end{array}$ & $\begin{array}{c}0.233 \\
(0.140)\end{array}$ & $\begin{array}{c}0.214 \\
(0.140)\end{array}$ & $\begin{array}{c}0.144 \\
(0.145)\end{array}$ \\
\hline
\end{tabular}

Dependent Variable: Fair/Poor Health

\begin{tabular}{lccclcccc}
\hline Unemployment Rate & 0.053 & 0.059 & 0.032 & & Unemployment Rate & 0.047 & 0.097 & 0.006 \\
& $(0.046)$ & $(0.051)$ & $(0.062)$ & & $(0.130)$ & $(0.143)$ & $(0.157)$ \\
& & & & & & & \\
Lagged Unemployment & 0.006 & -0.005 & -0.023 & Lagged Unemployment & -0.023 & 0.039 & 0.061 \\
Rate & $(0.050)$ & $(0.053)$ & $(0.058)$ & Rate & $(0.155)$ & $(0.145)$ & $(0.151)$
\end{tabular}

Dependent Variable: Excellent Health

\begin{tabular}{lccclcccc}
\hline Unemployment Rate & -0.103 & -0.194 & -0.394 & & Unemployment Rate & 0.103 & 0.108 & $0.134^{*}$ \\
& $(0.299)$ & $(0.294)$ & $(0.426)$ & & $(0.064)$ & $(0.066)$ & $(0.069)$ \\
& & & & & & & \\
Lagged Unemployment & $-0.432^{*}$ & -0.411 & $-0.525^{*}$ & Lagged Unemployment & 0.041 & 0.029 & 0.013 \\
Rate & $(0.256)$ & $(0.265)$ & $(0.301)$ & Rate & $(0.074)$ & $(0.080)$ & $(0.092)$
\end{tabular}

Dependent Variable: Sick Days

\begin{tabular}{lccclccc} 
Unemployment Rate & 0.03 & 0.039 & 0.056 & Unemployment Rate & $0.122^{* *}$ & $0.104^{*}$ & 0.096 \\
& $(0.043)$ & $(0.043)$ & $(0.051)$ & & $(0.060)$ & $(0.057)$ & $(0.068)$ \\
Lagged Unemployment & -0.005 & -0.003 & 0.005 & Lagged Unemployment & 0.026 & 0.024 & 0.051 \\
Rate & $(0.048)$ & $(0.047)$ & $(0.045)$ & Rate & $(0.054)$ & $(0.057)$ & $(0.053)$ \\
& & & & & & & \\
\hline State and Age-Year FE & Yes & Yes & Yes & State and Age-Year FE & Yes & Yes & Yes \\
State-Year Controls & No & Yes & Yes & State-Year Controls & No & Yes & Yes \\
State Trends & No & No & Yes & State Trends & No & No & Yes \\
\hline
\end{tabular}

Notes: Standard errors (in parentheses) are clustered at the state level. Health data are from the 1997-2012 Person and Child Files of the National Health Interview Survey. State monthly unemployment rates are from the Bureau of Labor Statistics. State control variables include the state average home price, the number of births, the fraction of the population in each of three education groups, and the fraction of the population in each of three race groups in a given year. ${ }^{*} \mathrm{p}<0.10,{ }^{* *} \mathrm{p}<0.05,{ }^{* * *} \mathrm{p}<0.01$. 
Table A3: Correlations Between Male and Female Predicted Employment Growth Rates and Parent Characteristics

\begin{tabular}{|c|c|c|c|}
\hline & $\begin{array}{l}\text { Father is the } \\
\text { Respondent }\end{array}$ & $\begin{array}{c}\text { Mother Reports } \\
\text { Any Mental } \\
\text { Health Conditions } \\
\end{array}$ & $\begin{array}{c}\text { Father Reports } \\
\text { Any Mental } \\
\text { Health Conditions }\end{array}$ \\
\hline Predicted Male & 0.288 & -0.221 & -0.237 \\
\hline Employment Growth & $(0.287)$ & $(0.364)$ & $(0.292)$ \\
\hline Predicted Female & -0.281 & 0.409 & -0.153 \\
\hline Employment Growth & $(0.377)$ & $(0.412)$ & $(0.500)$ \\
\hline Sample Mean & 24.81 & 12.66 & 8.208 \\
\hline \multicolumn{4}{|c|}{$\begin{array}{l}\text { Notes: Standard errors (in parentheses) are clustered at the state level. Data on the type of } \\
\text { respondent are from the } 1997-2012 \text { Person file. Data on parent mental health conditions are } \\
\text { from the sample adult file which randomly samples one adult from each household to ask } \\
\text { detailed questions on their health and health behaviors. Mother (Father) Reports Any Menta } \\
\text { Health is an indicator variable equal to one if the parent reported often feeling any of the } \\
\text { following: sad, nervous, restless, hopeless, worthless, or that everything requires effort. These } \\
\text { results were also robust to using a z-score index of these reported mental health } \\
\text { problems. Sample sizes for the adult sample outcomes range from } 91202 \text { to } 159000 \text {. Labor } \\
\text { demand indices, described in detail in Section IV, are created using data from the decennial } \\
\text { Census and Current Population Surveys. State-year control variables include state average home } \\
\text { prices, number of births, fraction of the population in each of three education groups, and } \\
\text { fraction of the population in a given race group in a year. Estimated models include state and } \\
\text { age-year fixed effects. } * \mathrm{p}<0.10, * * \mathrm{p}<0.05, * * * \mathrm{p}<0.01 \text {. }\end{array}$} \\
\hline
\end{tabular}


Table A4: Correlations Between Male and Female Predicted Employment Growth Rates and Family Background Characteristics

\begin{tabular}{lcccccc}
\hline \hline & $\begin{array}{c}\text { Black } \\
\text { Child }\end{array}$ & $\begin{array}{c}\text { Hispanic } \\
\text { Child }\end{array}$ & $\begin{array}{c}\text { Child is } \\
\text { Female }\end{array}$ & $\begin{array}{c}\text { Married } \\
\text { Parent }\end{array}$ & $\begin{array}{c}\text { Parent } \\
\text { School } \\
\text { Dropout }\end{array}$ & $\begin{array}{c}\text { Parent } \\
\text { Some } \\
\text { College }\end{array}$ \\
\hline Predicted Male & -0.0411 & -0.277 & -0.0114 & 0.0922 & 0.236 & -0.453 \\
Employment Growth & $(0.183)$ & $(0.193)$ & $(0.174)$ & $(0.202)$ & $(0.323)$ & $(0.314)$ \\
Predicted Female & 0.00596 & 0.140 & -0.0272 & -0.333 & -0.270 & -0.0432 \\
Employment Growth & $(0.257)$ & $(0.257)$ & $(0.200)$ & $(0.335)$ & $(0.344)$ & $(0.404)$ \\
\hline Sample Mean & 15.44 & 19.34 & 48.87 & 69.79 & 13.92 & 49.63 \\
\hline \hline
\end{tabular}

Notes: Standard errors (in parentheses) are clustered at the state level. Labor demand indices, described in detail in Section IV, are created using data from the decennial Census and Current Population Surveys. State control variables include the state average home price, the number of births, the fraction of the population in each of three education groups, and the fraction of the population in each of three race groups in a given year. Estimated models include state and age-year fixed effects. ${ }^{*} \mathrm{p}<0.10,{ }^{* *} \mathrm{p}<0.05$, $* * * \mathrm{p}<0.01$. 
Table A5: The Effect of Male and Female Predicted Employment Growth Rates on Child Health Including the Aggregate Unemployment Rate as a Control

General Measures of Child Health

Specific Child Health Outcomes

\begin{tabular}{|c|c|c|c|c|c|c|c|}
\hline & Model 1 & Model 2 & Model 3 & & Model 1 & Model 2 & Model 3 \\
\hline \multicolumn{4}{|c|}{ Dependent Variable: Costly Conditions Index } & \multicolumn{4}{|c|}{ Dependent Variable: Asthma } \\
\hline Predicted Male & $-0.009 * *$ & $-0.009 * *$ & $-0.008 *$ & Predicted Male & $-0.260 *$ & $-0.272 *$ & $-0.270 *$ \\
\hline Employment Growth & $(0.004)$ & $(0.004)$ & $(0.004)$ & Employment Growth & $(0.137)$ & $(0.136)$ & $(0.138)$ \\
\hline Predicted Female & $0.014 * *$ & $0.014 * *$ & $0.012 * *$ & Predicted Female & 0.226 & 0.208 & 0.227 \\
\hline Employment Growth & $(0.005)$ & $(0.005)$ & $(0.006)$ & Employment Growth & $(0.167)$ & $(0.162)$ & $(0.157)$ \\
\hline \multicolumn{4}{|c|}{ Dependent Variable: Fair/Poor Health } & \multicolumn{4}{|c|}{ Dependent Variable: Ear Infections } \\
\hline Predicted Male & -0.022 & -0.025 & -0.005 & Predicted Male & -0.048 & -0.077 & -0.069 \\
\hline Employment Growth & $(0.059)$ & $(0.063)$ & $(0.065)$ & Employment Growth & $(0.151)$ & $(0.143)$ & $(0.140)$ \\
\hline Predicted Female & 0.093 & 0.094 & 0.084 & Predicted Female & 0.150 & 0.176 & 0.181 \\
\hline Employment Growth & $(0.065)$ & $(0.066)$ & $(0.071)$ & Employment Growth & $(0.198)$ & $(0.198)$ & $(0.195)$ \\
\hline
\end{tabular}

Dependent Variable: Excellent Health

$\begin{array}{lccclcccc}\text { Predicted Male } & 0.108 & 0.153 & 0.203 & & \text { Predicted Male } & -0.017 & -0.012 & -0.023 \\ \text { Employment Growth } & (0.356) & (0.374) & (0.387) & \text { Employment Growth } & (0.083) & (0.087) & (0.089) \\ & & & & & & & & \\ & & & & & & & \\ \text { Predicted Female } & -0.678^{*} & -0.698^{*} & -0.778^{*} & \text { Predicted Female } & 0.159 & 0.154 & 0.174 \\ \text { Employment Growth } & (0.349) & (0.367) & (0.399) & \text { Employment Growth } & (0.104) & (0.106) & (0.108)\end{array}$

Dependent Variable: Sick Days

$\begin{array}{lccclcccc}\text { Predicted Male } & -0.047 & -0.049 & -0.062 & \text { Predicted Male } & -0.111^{*} & -0.106 & -0.089 \\ \text { Employment Growth } & (0.042) & (0.046) & (0.043) & \text { Employment Growth } & (0.064) & (0.067) & (0.068) \\ & & & & & & & \\ & & & & & & & \\ \text { Predicted Female } & 0.123^{*} & 0.119 & 0.134^{*} & \text { Predicted Female } & 0.136 & 0.133 & 0.115 \\ \text { Employment Growth } & (0.067) & (0.071) & (0.068) & \text { Employment Growth } & (0.084) & (0.084) & (0.086)\end{array}$

\begin{tabular}{llllllll}
\hline State and Age-Year FE & Yes & Yes & Yes & State and Age-Year FE & Yes & Yes & Yes \\
State-Year Controls & No & Yes & Yes & State-Year Controls & No & Yes & Yes \\
State Trends & No & No & Yes & State Trends & No & No & Yes \\
\hline \hline
\end{tabular}

Notes: Standard errors (in parentheses) are clustered at the state level. Health data are from the 1997-2012 Person and Child Files of the National Health Interview Survey. Labor demand indices, described in detail in Section IV, are created using data from the decennial Census and Current Population Surveys. State control variables include the state average home price, the number of births, the fraction of the population in each of three education groups, and the fraction of the population in each of three race groups in a given year. ${ }^{*} \mathrm{p}<0.10,{ }^{* *} \mathrm{p}<0.05, * * \mathrm{p}<0.01$. 